\title{
A CENTRALIDADE DO TRABALHO NA FORMAÇÃO SOCIAL DA VILA DE MARZAGÃO
}

\author{
Rodrigo Pletikoszits de Ávila*
}

Resumo: Este artigo tem por objetivo identificar e discutir a construção de estratégias e de um padrão disciplinar nas relações de trabalho na antiga fábrica de tecidos da vila de Marzagão. Esta vila operária de fins do século XIX, localizada no município de Sabará - MG, chegou a contar com cerca de dois mil moradores. Possuía uma infraestrutura totalizante, na qual os moradores não precisavam sair do local de trabalho para estudar, manifestar suas crenças religiosas, festejar, ou mesmo consumir. As mudanças ocorridas no contexto político-econômico do país, associadas a questões administrativas internas afetaram diretamente a vida dos operários desta fábrica. A vila que viveu seu apogeu entre as décadas de 1920 e 1950, começou a declinar. A partir da década de 1960 a fábrica e a vila passaram por um processo de desestruturação. A análise deste caso pode contribuir para a compreensão das relações sociais do trabalho em fábricas similares de períodos correlatos.

Palavras-chave: Vilas operárias, disciplinamento do trabalhador, Marzagão (Sabará-Minas Gerais).

\begin{abstract}
This article has because of identifying objective and discussing the construction of strategies and of a disciplinal standard in the relations of work in the ancient factory of cloths of Marzagão. This working town of ends of the century XIX, when MG was located in the local authority of Sabará-, came counting with around two thousand residents. It had an totality structure, in which the residents were not needing to go out from the place of work to study, to show his religious beliefs, to celebrate, or even to consume. The changes occurred in the context economical-politician of the country, associated to the administrative internal questions affected straightly the life of the workers. The town that survived his apogee between the decades of 1920 and 1950, began to go down. From the decade of 1960 the factory and the town suffer a process of decadence. The analysis of this case can contribute to the understanding of the social relations of the work in similar factories of the same periods.
\end{abstract}

Key-words: Workers towns, workers disciplining, Marzagão (Sabará-Minas Gerais).

O objetivo deste texto é contextualizar, através da delimitação teórica e empírica, a trajetória histórica da atividade do trabalho construída no lugar conhecido como Marzagão. Sabendo-se que existe uma multiplicidade de enfoques possíveis para se abordar este tema, foram feitas algumas escolhas dentro do que existe de documentação disponível. Embora a documentação institucional, como regimento e estatutos internos de funcionamento da fábrica, não tenham sido disponibilizados pelos proprietários da antiga fábrica para a execução deste trabalho, a comparação com outras fábricas e modelos fabris do mesmo período, que associavam local de trabalho e moradia, implantados na mesma época em Minas e em outras partes do país, permitem criar um quadro comparativo de aspectos que

\footnotetext{
* Mestre em Ciências Sociais pela PUC Minas e Bacharel em História pela mesma instituição.
} 
são convergentes e semelhantes mesmo em situações aparentemente diversas. Os documentos disponíveis em meios de pesquisa pública utilizados para descrever a trajetória e o contexto histórico da fábrica de Marzagão, principalmente em seus primeiros anos de existência, baseiam-se, fundamentalmente, em artigos de revistas e jornais de Sabará e de Belo Horizonte. Nesses artigos, a estrutura fabril e as características paternalistas dos dirigentes e proprietários da fábrica de tecidos são destacadas. A exaltação do trabalho na indústria e a divulgação das condições de vida favoráveis oferecidas aos trabalhadores que viviam inseridos no cotidiano dessas vilas operárias eram estratégias comuns durante 0 período de industrialização brasileira entre fins do século XIX e início do século XX.

Esta descrição é contraposta com bibliografia existente sobre o tema do trabalho em vilas operárias para que sejam identificadas questões pertinentes à constituição social e às contradições entre o mundo do capital e do trabalho.

O conjunto arquitetônico de Marzagão representa um exemplar das transformações correlatas ao desenvolvimento industrial ocorridas em diversas cidades brasileiras durante fins do século XIX e primeiras décadas do século XX. Dentre as mudanças processadas no cotidiano e nos modos de vida urbanos de núcleos industriais, encontram-se a desconstrução da cidade colonial, a modernização e racionalização da infra-estrutura urbana e as reformas da habitação.

A estratégia e os procedimentos adotados para a implantação de uma fábrica de tecidos e a própria escolha da atividade têxtil como mola propulsora da indústria moderna durante fins do século XIX, no Brasil, apontavam para uma conveniente condução desta atividade, com condições mercadológicas e fiscais favoráveis.

Ao longo da história da industrialização brasileira, principalmente a partir de meados do século XIX, foi difundida a prática de construção de moradias para operários por empresas em cidades ou em localidades rurais. Estes conjuntos arquitetônicos foram denominados de várias formas ao longo de suas existências. Comumente chamados de vilas operárias, núcleos urbanos, cidade-companhia ou cidade operária, estes locais possuem diferenças quanto a localizações, condições político-administrativas e ao período histórico em que ocorrem suas construções.

Originalmente usado no Brasil para nomear um grupo de moradias destinadas a operários de um mesmo empreendimento fabril, o termo "vila operária" logo seria estendido para designar grupos de casas modestas semelhantes produzidas por outros 
agentes. Sob a denominação "vila operária", eram reunidas no país, até os anos trinta, as experiências mais diversas: conjuntos construídos por empresas imobiliárias para aluguel ou venda a proletários urbanos, por empresas ferroviárias para seus funcionários, por indústrias, minas, frigoríficos e usinas para seus operários, técnicos e administradores, e pelo Estado. Posteriormente, o termo "conjunto habitacional" se difunde, tanto em referência às moradias em blocos de apartamento, quanto às casas unifamiliares. $^{1}$

No Brasil, durante as primeiras décadas do século $X X$, as vilas operárias surgiam como proposta de moradia simples, mas que apresentavam padrões de higiene, conforto e ordenamento espacial não existente nos cortiços e favelas. Ao morador de uma vila operária, tinha-se associada à idéia de um trabalhador com emprego regular e com relações de vizinhança estáveis.

O termo surge para designar aglomerações isoladas no campo, como, por exemplo, em um projeto de construção de uma grande metalúrgica em Frutal, publicado em 1920, no qual há menção à construção de uma "villa operaria" com 2.500 casas. Camaragibe é referida como uma "villa operária" na fala de conferencistas do Congresso Católico, ocorrido em 1902, e em um boletim da Companhia Industrial Pernambucana para a Exposição Nacional de 1908, quando contava com 123 casas, dois alojamentos para solteiros, duas escolas, armazém, padaria, consultório médico e Círculo Operário. ${ }^{2}$

No caso específico de Marzagão, a fábrica surge onde anteriormente existia uma fazenda. O nome desta fazenda refere-se a uma feitoria portuguesa localizada na costa africana, de onde teriam vindo alguns colonizadores do território mineiro. A ocupação desse território ocorreu ainda no século XVIII vinculada ao povoado do Curral Del Rei. A fazenda de Marzagão surge enquanto uma mancha de ocupação entre os limites do Curral Del Rei e a Vila de Sabará.

O local teve, ao longo de sua trajetória histórica, diversos termos que o designavam. Após a construção da fábrica, em fins do século XIX, a fazenda do Marzagão ficou conhecida como a fábrica do Marzagão. Em jornais e revistas da capital mineira e do município de Sabará o local já foi chamado de arraial, vila e conjunto. Para efeito legal-jurídico o IEPHAMG, durante o processo de tombamento do local em 2002, utilizou a expressão "Conjunto Arquitetônico e Paisagístico da Vila Elisa, Vila operária e Antiga Fábrica de Tecidos de

\footnotetext{
1 CORREIA, Telma de Barros. "De vila operária a cidade - compahia: as aglomerações criadas por empresas no vocabulário especializado e vernacular." Revista Brasileira de Estudos Urbanos e Regionais, n. 4, p.83-98, mai.2001, p. 84

2 Ibidem, p. 85.
} 
Marzagão do município de Sabará". "Os termos vila operária, núcleo urbano, núcleo residencial e núcleo fabril referem-se a pequenas aglomerações isoladas, diferentes de uma cidade em termos de escala e do grau de autonomia dos moradores e da vida local em relação à empresa." ${ }^{3}$

O termo vila operária é comumente utilizado para nomear grupos de casas, algumas vezes acompanhados de equipamentos coletivos, como escola, igreja ou clube, localizados dentro de cidades ou em subúrbios. A adequação da utilização e da uniformização destas expressões é muitas vezes divergente, pois nem sempre a expressão está levando em consideração a relação entre o significado histórico destes termos com o local que recebe esta denominação. Em Sabará o local que abrigou a fábrica de tecidos e as residências de operários juntamente com toda uma infra-estrutura para a manutenção da vida destes pertence administrativamente ao distrito Carvalho de Brito, entretanto, o local é conhecido popularmente apenas como Marzagão.

Recuperar a história desses núcleos no Brasil é, sob muitos aspectos, entender o sentido das rápidas transformações de sua configuração espacial. Transformações que podem significar, muitas vezes, seu total desaparecimento após poucas décadas de existência e que exigem, por outro lado, o recurso contínuo a novas designações capazes de definir e precisar cada uma das formas novas assumidas por esses lugares. ${ }^{4}$

Delimitadas as possibilidades de compreensão do que veio a ser o que podemos chamar de vila operária de Marzagão, propõe-se compreender o contexto histórico de constituição das indústrias têxteis a partir do momento da construção destas edificações, vinculados ao processo de transformação do mundo do trabalho nas indústrias.

O período de industrialização em Minas Gerais intensificou-se somente no terceiro quartel do século XIX. Podemos considerar este momento como uma fase de transição entre as propostas de um progresso civilizador, da industrialização, do trabalho livre assalariado, das máquinas em contraposição a um mundo considerado incivilizado, agrícola, monocultor e de mão-de-obra essencialmente escrava.

Uma das características da produção interna em Minas era a diversidade. 0 abastecimento interno era tão importante quanto o setor destinado à exportação. (LIBBY,

\footnotetext{
${ }^{3}$ CORREIA, Telma de Barros. “De vila operária a cidade - compahia: as aglomerações criadas por empresas no vocabulário especializado e vernacular." Revista Brasileira de Estudos Urbanos e Regionais, n. 4, p. 83-98, mai.2001, p. 84

4 Ibidem, p. 196.
} 
1988)..$^{5}$ A partir da década de 1890 o setor têxtil passou por alguns ajustes, devido à transição ocorrida nas políticas públicas no Brasil. A abolição da escravidão e a diversificação do mercado interno impulsionaram os empresários a racionalizar os modos de produção, visando aumentar a competitividade e a produtividade. Neste período, dada a diversidade existente na produção da região central do estado de Minas Gerais, a construção de fábricas convergiu para esta região e beneficiou a construção da capital, criando também um eficiente sistema de transportes, com a implantação de ramais de trens que atuaram como um facilitador para o escoamento da produção destas fábricas. ${ }^{6}$

Alguns pontos são comuns em várias fábricas mineiras. A fábrica de Marzagão e a fábrica Cedro Cachoeira, analisada por Domingos Giroletti, possuem algumas semelhanças no que se refere às formas criadas pelos empresários na constituição das estratégias empresariais de controle do operariado não apenas durante o trabalho, mas "nas demais agências de socialização que foram criadas ou introduzidas nas vilas operárias". 7

Segundo Giroletti, "As fábricas foram, no período, as unidades produtivas em condições de empregar trabalhadores e de transformá-los de forma rápida e eficiente em operários industriais". ${ }^{8}$ A chance de inserção social apresentava-se dentro da lógica da venda da mão-de-obra e da submissão a uma estratégia disciplinar até então pouco explorada em Minas Gerais. Nesta lógica incluíam-se também as crianças, sob o argumento de formação de bons cidadãos, habilidosos e disciplinados.

O sistema produtivo industrial mecanizado estabeleceu novos parâmetros para as fábricas de tecidos bem como para os operários que viessem a trabalhar nelas. Algumas técnicas de submissão/dominação tornam-se invisíveis no exercício do poder. Quanto mais discreto o mecanismo de poder, mais eficiente ele se torna.

Na prática de um processo de qualificação de mão-de-obra, com o treinamento técnico ou com a criação/interiorização de novos valores, já está formando um trabalhador disciplinado. Isso é tão consensual que os teóricos e as pesquisas sobre essa problemática não reservam geralmente à formação da disciplina um tratamento específico e distinto. Dá-se por suposto que a disciplina vem embutida na prática pedagógica, na aprendizagem técnica e na incorporação de novos valores e normas.

\footnotetext{
${ }^{5}$ LIBBY, Douglas Cole. Transformação do trabalho em uma economia escravista - Minas gerais no Século XIX. São Paulo: Brasiliense, 1988.

${ }^{6}$ GIROLETTI. Domingos. Fábrica: Convento e Disciplina. Brasília: Editora UNB, 2002, p. 29

7 Ibidem.

8 Ibidem, p. 93.
} 
Os dispositivos disciplinares existentes em uma vila operária que atua em diferentes setores da vida de um indivíduo manifestam-se para além das práticas que operam no mundo do trabalho e que segundo Foucault expressam-se na "submissão das forças e dos corpos". ${ }^{9}$

Antes de iniciar a exposição do contexto de industrialização de Minas Gerais, propõe-se citar algumas possibilidades acerca das concepções do conceito de trabalho ao longo de sua trajetória histórica.

Na obra de Denis Huisman e André Vergez o conceito de trabalho é considerado sob diferentes interpretações. Primeiramente, é analisada a origem etimológica do termo trabalho, que está relacionada à noção que se tem de sofrimento e castigo."(...) para os gregos, o trabalho exprime a miséria do homem, não a sua nobreza." ${ }^{10}$ Entretanto, existem outras concepções modernas acerca do conceito de trabalho que o interpretam enquanto uma possibilidade de libertação. Para Hegel, esta noção de libertação é exposta no episódio do senhor e do escravo, em que em uma situação hipotética de combate a vida dos concorrentes seria colocada em risco. O ganhador não mataria o perdedor da luta, mas este se submeteria ao trabalho servil. A partir daí ter-se-ia o senhor e o escravo. O senhor, em sua ociosidade, não conheceria o processo de transformação da natureza realizado pelo escravo que recuperaria a liberdade por meio do domínio da natureza. "O trabalho surge então como a expressão da liberdade reconquistada" ${ }^{11}$

São inúmeras as interpretações e acepções que o trabalho adquiriu ao longo de sua trajetória histórica. Annie Jacob, ao analisar as transformações do termo relacionando-o com o pensamento econômico liberal, argumenta que:

Enquanto, na representação tradicional, o trabalho é um dever para quem não pode garantir sua subsistência de outro jeito, a economia, para fazer com que esse trabalho "produza", constrói uma moral social. (...) Os valores que os economistas ajudaram a promover vão bem além de uma simples racionalidade, em busca de eficácia. São valores morais, puritanos, baseados em uma "interiorização de normas". Max Weber (1920) mostrou muito bem como esses valores contribuíram para o desenvolvimento do "espírito do capitalismo". ${ }^{12}$

\footnotetext{
${ }^{9}$ GIROLETTI, Domingos. Fábrica: convento e disciplina. Brasília: Editora UNB, 2002, p. 195.

10 HUISMAN, Denis; VERGEZ, André. Curso moderno de filosofia: introdução à filosofia das ciências. Rio de Janeiro : Biblioteca Universitária Freitas Bastos, 1976, p. 196.

${ }^{11}$ Neste momento faz-se aqui apenas uma referência à dualidade intrínseca ao conceito de trabalho. A exposição mais ampla sobre o assunto encontra-se expressa no texto citado.

12 JACOB, Annie. H. Vérin. Emergência do valor social do trabalho no pensamento econômico do século XVIII. Tradução: Leila de Melo Franco Sarieddine Araújo. Paris: L'Harmattan, 1995, p. 1.
} 
Considerando-se as discussões atuais sobre o mundo do trabalho, nota-se que segue em curso uma corrente difusora de uma crise da centralidade do trabalho diante de uma questão ainda não equacionada no que se refere à subordinação do trabalho ao capital. $^{13}$ É com base no impasse e nas contradições do sistema produtivo que se propõe pensar algumas das características específicas e locais das relações de trabalho e suas implicações conjunturais, aplicadas no caso da vila operária de Marzagão.

Atualmente a centralidade do trabalho é colocada em questão por uma série de fatores, dentre eles pode-se citar a concentração de grandes massas de trabalhadores à margem do processo produtivo, a precarização na configuração do trabalho e do emprego, dentre outros que se instauraram após o processo de reestruturação produtiva ocorrida a partir década de 1970.

Em fins do século XVIII e fundamentalmente no século XIX, durante o processo de industrialização de diversos países, a questão da centralidade do trabalho encontrava-se como paradigma difundido pelas nações em que o capitalismo era uma prática crescente.

No Brasil, a segunda metade do século XIX foi o momento em que o processo de industrialização se fez evidente, tendo como principais protagonistas o Estado e os empresários privados. Segundo Domingos Giroletti:

\footnotetext{
A elite imperial iniciou o processo de modernização pela infra estrutura, notadamente, pelos transportes: a ferrovia, a rodovia e a navegação costeira e fluvial; pelas comunicações: o telégrafo, o melhoramento dos serviços do Correio Nacional, o telefone. Essas mudanças possibilitaram uma maior integração econômica, política e administrativa da capital com as províncias e vice-versa. ${ }^{14}$
}

Dentre as atividades industriais mais comuns implementadas no Brasil a partir da década de 1870, encontravam-se as fábricas de fiação e tecelagem. O setor têxtil esteve à frente da maior parte dos empreendimentos organizados até a década de 1930. Uma maior diversificação do setor industrial passa a ocorrer após esse período.

\footnotetext{
13 Acerca da discussão teórica deste tema, toma-se como referência a obra: ANTUNES, Ricardo. Os sentidos do trabalho. Ensaio sobre a afirmação e a negação do trabalho.

${ }^{14}$ GIROLETTI, Domingos. Fábrica: convento e disciplina. Brasília: Editora UNB, 2002, p. 12.
} 


\section{A CONSTRUÇÃO DE UMA VILA OPERÁRIA}

A fábrica de tecidos localizada no município de Sabará, às margens do ribeirão Arrudas, tem sua constituição e idealização iniciada em 1878. Neste período, em território pertencente ao Curral Del Rei, surge encravada em meio a encostas de vegetação rasteira e densas matas circundantes, uma fábrica de tecidos como relatou Abílio Barreto:

Pouco depois, em 1878, um outro acontecimento glorioso para o município de Sabará, e particularmente grato ao Curral Del Rei, verificou-se nas suas vizinhanças. Por um grupo de sabarenses empreendedores e inteligentes, à frente dos quais se achava o Sr. Francisco Cândido Guimarães, foi organizada a Companhia Industrial Sabarense e com ela fundada a Fábrica de Tecidos Marzagão. ${ }^{15}$

O território conhecido como Marzagão sofreu modificações ao longo de sua existência, tanto em seu nome quanto à subordinação administrativa. Na segunda metade do século XIX, momento em que foi constituída a Companhia Industrial Sabarense, a região de Marzagão foi considerada parte constitutiva do Curral Del Rei. Esta condição administrativa do lugar permaneceu após a construção de Belo Horizonte até o ano de 1938, momento em que através do Decreto Lei no 148 o local foi desmembrado do território da capital e passou a integrar o município de Sabará, situação que permanece até os dias atuais. O local teve seu nome juridicamente alterado. A modificação em seu nome justificouse pelo motivo de haver uma localidade homônima no Estado de Goiás, o que ocasionava freqüentes extravios de correspondências. Sendo assim, em dezembro de 1943, pelo Decreto Lei no 1.058, a região passou a denominar-se Marzagânia. Em 1962, a denominação do local foi alterada através da Lei $\mathrm{n}$ - 2.764 , passando a compor parte de um distrito do município de Sabará que recebeu o nome de Carvalho de Brito, em homenagem ao antigo proprietário da fábrica de tecidos.

Embora os primeiros passos para a constituição da empresa tenham ocorrido em 1878, os estatutos da Companhia Industrial Sabarense foram assinados pelos acionistas em 11 de janeiro de 1880 e anexos ao Decreto n. 7813 de agosto do mesmo ano. Não é precisa a data de início das atividades em Marzagão, entretanto sabe-se que em agosto de 1883 a

\footnotetext{
15 BARRETO, Abílio. Belo Horizonte - Memória Histórica e Descritiva - História Antiga. v.1. Belo Horizonte: Fundação João Pinheiro, 1996, p. 221.
} 
fábrica já se encontrava em funcionamento, como pode ser observado na fala do presidente da província Antônio Gonçalves Chaves, em 2 de agosto de 1883:

A fábrica de tecidos da Companhia Industrial Sabarense estabelecida na fazenda do Marzagão, freguesia da cidade de Sabará, possue um grande motor hydraulico de força de 80 cavallos; fiação completa e 1800 fuzos de Mer. Robert, aperfeiçoados, fazendo 7,200 evoluções por minuto, 48 teares para tecidos lisos, trançados, xadrezes e para phantasias, caldeira a vapor para engomação e todas as machinas necessarias para a promptificação dos tecidos até o seu completo acabamento. Empregão-s 80 a 100 operarios. Seo capital é de 250:000\$000. O consumo de materia prima (algodão) é de 1:000 a 1:200 kilos diariamente, ou de 300.000 kilos por anno. Produz diariamente 2.000 metros de tecidos, variando o preço de 200 a 700 rs . por metro. ${ }^{16}$

A fala acima citada permite inferir que já no ano de 1883 a fábrica de tecidos de Marzagão possuía um bom nível de mecanização e sistematização da produção e contava com setores diversificados no processo de produção, como a fiação, a caldeiraria e a engomação.

Em 1885 a fábrica de Marzagão tinha uma das maiores produções anuais em metros de tecidos e consumo de algodão de Minas Gerais, com cerca de 600.000 metros ao ano e 300.000 quilos de algodão. A fábrica mineira que atingia a mesma produtividade era a Cachoeira, localizada no município de Sete Lagoas. Porém, a diferença estava entre as dimensões das duas fábricas. Enquanto a fábrica Cachoeira contava com 2.000 fusos, 60 teares e 140 funcionários, Marzagão tinha 1.800 fusos, 18 teares e 100 funcionários. ${ }^{17}$

O pólo irradiador das técnicas e maquinários empregados na indústria, durante o século XIX e início do século XX, fundamentalmente no setor têxtil, era, certamente, a Inglaterra. Sendo assim, continuando seu relato sobre a construção da fábrica em Marzagão, Abílio Barreto relata que:

Espírito perspicaz de industrial adiantado e inteligente, o Sr. Francisco Guimarães, em 1886, deliberou e empreendeu uma viagem à Inglaterra, onde adquiriu, entre outras máquinas, um pequeno dínamo gerador de eletricidade, que trouxe para Marzagão, instalando-o nesse mesmo ano, quando Minas ainda não conhecia eletricidade, senão pelo que a respeito dela se dizia. Era uma pequena máquina movida por força hidráulica,

\footnotetext{
${ }^{16}$ CHAVES, Antônio Gonçalves. Fala dirigida à assembléia Provincial de Minas Gerais na segunda sessão da 24a legislatura, em 2 de agosto de 1883. Tipografia do Liberal Mineiro, Ouro Preto, 1883, p. 42.

${ }^{17}$ JACOB, op. cit., p. 269.
} 
com uma capacidade iluminativa para 20 lâmpadas, a qual ainda hoje existe no almoxarifado da fábrica. ${ }^{18}$

Os principais envolvidos em empreendimentos industriais, em fins do século XIX, ou tinham alguma ligação com a administração estatal ou eram fazendeiros locais. Em Marzagão, além do referido Francisco Cândido Guimarães, constam entre os fundadores e primeiros diretores da Companhia os nomes do Coronel Jacinto Dias da Silva, Deputado Provincial, Presidente da Câmara de Sabará e chefe do Partido Liberal, que teria sido o 10 Presidente, e os sabarenses Prof. Séptimo de Paula Rocha e Domingos de Figueiredo Lima.

Convém lembrar que o período de implantação e difusão de fábricas e indústrias têxteis no século XIX ocorreu em uma época em que o país passava por um processo de reorganização do processo produtivo e oscilava entre o fim do trabalho escravo e o aumento trabalho assalariado, o fim da monarquia e o início do governo republicano, o aumento da urbanização e o paradigma externo do desenvolvimento calcado fundamentalmente na mecanização dos modos de produção.

Pode-se dizer que o período de implantação da indústria mineira, assim como da fábrica de Marzagão, foi proveniente de uma conjuntura das relações de trabalho desenvolvidas em um plano não só nacional, mas com fortes influências internacionais. Os ideais de progresso e civilização, associados a diversos incentivos estatais como isenção de impostos, facilidade de importação de maquinário e investimentos nos setores de transporte, facilitaram, em alguns aspectos, a expansão da atividade fabril, não somente em Minas Gerais, mas em todo o país.

Em Minas Gerais, por volta de 1870, as dificuldades de escoamento de mercadorias produzidas em diferentes regiões e o desenvolvimento de atividades agrícolas, bem como da pecuária, encontram-se em pauta nas discussões do governo provincial, como se pode verificar na fala do presidente ao referir-se à economia provincial: "O meio único de salvação é dar sahida à sua produção actual, fornecendo-lhe ao mesmo tempo recursos ao

\footnotetext{
18 BARRETO, Abílio. Belo Horizonte - Memória Histórica e Descritiva - História Antiga. v.1 Belo Horizonte: Fundação João Pinheiro, 1996, p. 221.
} 
desenvolvimento, de sua lavoura e industrias, aplicando em seu ubérrimo solo sementes novas, apparelhos e machinas aperfeiçoadas, por intermédio das estradas de ferro."19

A questão da construção de estradas de ferro pode ser interpretada através de duas vertentes. Algumas indústrias têxteis sofreram com a implantação de estradas de ferro e com a conseqüente concorrência de produtos importados, que passaram a chegar com maior facilidade com a construção da ferrovia. Em Marzagão, a estrada de ferro contribuiu para a estruturação da vila operária atendendo os interesses do corpo administrativo de Marzagão e equacionando parte do problema de transporte da produção e de matériaprima. As ferrovias se enquadraram em um projeto de modernização brasileira. Após os investimentos de Irineu Evangelista, o Barão de Mauá, no Rio de Janeiro neste setor, o governo imperial incentivou e financiou através de um sistema de garantia de juros boa parte dos projetos de estrada de ferro em diversas regiões brasileiras.

O investimento estatal e a expansão dos transportes ferroviários tornaram-se evidentes em Marzagão no início do século XX. Em 1902 foi inaugurada uma estação com um pequeno desvio para atender a descarga de algodão na fábrica de tecidos. A estação, inaugurada com o nome de Marzagão e situada na linha tronco da estrada de ferro Central do Brasil, ligava General Carneiro à Belo Horizonte. Esse edifício passou a se chamar, em meados da década de 1950, estação Carvalho de Brito, em homenagem ao proprietário da vila operária. Esta edificação foi demolida na década de 1980.

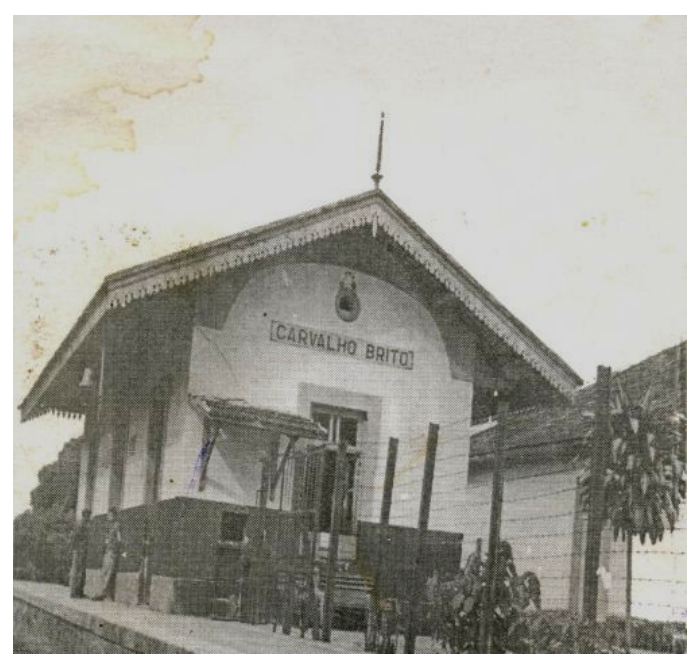

Imagem 2 - Estação Carvalho de Brito anos 1950. FONTE: www.estacoesferroviarias.com.br

\footnotetext{
191873 - RELATÓRIO com que o Sr. Senador Joaquim Floriano de Godoy, no dia 15 de janeiro de 1873 passou a administração da província de Minas Gerais ao 2o vice presidente Exm Sr. Dr. Francisco Leite da Costa Belém por ocasião de retirar-se para tomar assento. Ouro preto 1873. p.31.
} 
O lugar escolhido para a construção da fábrica distava dos núcleos urbanos existentes neste período. A sede da empresa localizava-se entre os núcleos populacionais mais próximos, ou seja, a sede de Sabará e o Curral Del Rei. Este referido lugar possuía, em fins do século XIX, apenas algumas fazendas que viviam da agricultura de subsistência.

O emprego em uma indústria tornou-se novidade para os moradores da região e atraiu a atenção de diversos trabalhadores rurais, que não viam perspectivas em sua atividade ou sentiram-se atraídos pela oferta de novas possibilidades trabalhando em uma indústria.

A partir daí começa a se delinear nesse lugar uma estratégia e uma série de procedimentos por parte de empresários para se criar a transformação de trabalhadores predominantemente agrários em trabalhadores fabris.

Ao alterar a paisagem rural da região e introduzir novas formas de produção, como ocorrido em outros empreendimentos da época, Giroletti argumenta que novos valores e uma nova visão de mundo eram estabelecidos. Sendo assim:

\footnotetext{
A estratégia empresarial visava formar nos operários um novo estilo de vida, uma nova ética e uma nova sexualidade que se contrapusessem à sistemática de viver do trabalho escravo, camponês ou artesão correspondente à nova formação econômico-social capitalista. O direito criado pelos regulamentos, prevendo penalidades e estímulos materiais, foi um dos principais meios utilizados para especificar os valores a serem transmitidos ao corpo operário e para criar neles uma nova cosmovisão. ${ }^{20}$
}

Por encontrar-se distante da moradia dos primeiros funcionários e buscando criar um modelo integrado entre o local de trabalho moradia, os empreendedores e proprietários da fábrica passaram a construir edificações para abrigar os funcionários no mesmo lugar da sede da empresa.

Os primeiros funcionários que se empregaram em fábricas de tecidos no Brasil, bem como seus respectivos empreendedores, passaram por um processo de transição entre o mundo do trabalho agrícola e escravocrata e as novas estratégias e configurações do trabalho assalariado.

${ }^{20}$ GIROLETTI, Domingos. Fábrica: convento e disciplina. Brasília: Editora UNB, 2002, p. 19. 
(...) A transição do trabalho escravo para o trabalho livre no Brasil do século XIX colocou as classes dominantes da época diante da necessidade premente de realizar ajustes no seu universo mental, de adequar a sua visão de mundo às transformações socioeconômicas que estavam em andamento. No mundo de outrora, ordenado pela presença do escravo, a questão do trabalho era escassamente problematizada na esfera das mentalidades: o trabalhador escravo era propriedade do senhor e, sendo assim, o mundo do trabalho estava obviamente circunscrito à esfera do mundo da ordem, que consagrava o princípio da propriedade. ${ }^{21}$

O modelo que agregava local de trabalho e moradia propunha integrar as relações sociais de trabalho ao cotidiano dos operários. A transformação, criação e formação de mãode-obra especializada partiram, em grande parte, da ação coordenada pelos empresários e empreendedores da atividade fabril.

Neste período, de fins do século XIX, a edificação de vila operária detentora de uma estrutura com características de auto-suficiência começa a surgir em meio à possibilidade de materializar uma série de projetos utópicos que eram carregados de um elevado nível de otimismo e crença no progresso civilizatório e no desenvolvimentismo científico. Habermas, ao analisar os projetos utópicos no século $\mathrm{XXI}$, verifica o atual esgotamento das energias utópicas da sociedade do trabalho, tendo em vista os efeitos colaterais e a ambivalência da transformação da natureza pela ação humana. Entretanto, ao expor as propostas utópicas clássicas e relacioná-las ao contexto do século XIX, demonstra que havia motivações bastante racionais para se crer nessas utopias nesse período.

As utopias clássicas traçaram as condições para uma vida digna do homem, para a felicidade socialmente organizada: as utopias fundidas ao pensamento histórico - que interferem nos debates políticos desde o século XIX - despertam expectativas mais realistas. Elas apresentam a ciência, a técnica e o planejamento como instrumentos promissores e seguros para um verdadeiro controle da natureza e da sociedade. ${ }^{22}$

Criou-se em Marzagão, uma condição disciplinar entre operários e empresários representada por um sistema de sanções e benefícios que foi eficazmente aplicado durante mais de três décadas.

As fábricas foram, no período, as unidades produtivas em condições de empregar trabalhadores e de transformá-los de forma rápida e eficiente em operários industriais.

\footnotetext{
${ }^{21}$ CHALHOUB, Sidney. Trabalho Lar \& Botequim. O cotidiano dos trabalhadores no Rio de Janeiro da Belle Époque. Campinas: Ed. Unicamp, 2001, p. 65.

${ }^{22}$ HABERMAS. J. A nova intransparência. Novos estudos Cebrap. no 18. São Paulo, 1987, p. 105.
} 
Os empresários tinham consciência de que as fábricas eram agências melhor aparelhadas para reprocessar mão-de-obra autóctone, no sentido de resgatá-la da escravidão (ou do infortúnio) e de incorporá-la econômica e socialmente à nova sociedade capitalista que se desenvolvia. ${ }^{23}$

Os limites de dominação e o modelo disciplinar criado em Marzagão tinham variadas fontes constituintes. A Igreja era uma instituição que se tornou presente e atuante nas formas de convívio dos habitantes do local desde seus primeiros anos de existência. Segundo matéria publicada pelo jornal católico denominado “O Apóstolo", em 1893, os operários de Marzagão teriam elaborado um abaixo assinado dirigido aos acionistas da fábrica, no qual pediam respeitosamente a ereção de uma capela sob a invocação do Sacratíssimo Coração de Jesus. Neste documento os operários argumentaram que:

Sem Deus nada! E para provar o que dizemos, lançai vossas vistas para a Europa, onde se tem feito timbre em afastar a religião do operário, e ali encontrareis a anarquia e a dinamite substituindo as duas melhores filhas da religião - a paz e a ordem. E nós, ficaremos como os desgraçados operários europeus? De certo que não, pois não nos dirigimos em vão a acionistas, entre os quais encontram-se estrênuos defensores e confessores do nosso sublime credo, que é a religião do crucificado. ${ }^{24}$

Nesse tom de crença incondicional e descritos pelo jornal católico como devotados fiéis, os trabalhadores da fábrica de Marzagão foram representados pelo operário Felismino Arruda, que assumiu a iniciativa da campanha e assim descreveu a entrega do abaixo assinado: "[...] um grupo de meninas conduziu uma inscrição composta pela professora. $\mathrm{O}$ gerente serviu vinho, prometeu apoio, ergueram-se brindes. A assembléia geral dos acionistas aprovou a solicitação em janeiro." ${ }^{25}$ Nota-se que neste período já se encontra na vila a presença de uma professora. Como poderemos observar mais adiante, a instituição de ensino existente no complexo fabril de Marzagão também era um setor controlado pelos proprietários.

\footnotetext{
${ }^{23}$ GIROLETTI, Domingos. Fábrica: convento e disciplina. Brasília: Editora UNB, 2002, p. 93-94.

24 O APÓSTOLO, 14/4/1893, p. 4.

25 O APÓSTOLO, 14/4/1893, p. 4.
} 


\section{O PERÍODO DE TRANSIÇÃO DA ADMINISTRAÇÃO E O APOGEU DA VILA OPERÁRIA}

Existe uma breve lacuna nas informações sobre os primeiros anos de funcionamento da fábrica de tecidos de Marzagão no início do século XX. Entretanto, sabese que durante as duas primeiras décadas do século $X X$, o investimento prosperou e se ampliou, como podemos observar nos relatos de Victor Silveira, que em 1925, ao descrever as atividades da fábrica afirma que: "Nada mostra, a nosso ver, com mais vivacidade, o progresso de Minas, no campo da indústria, do que esta fábrica, cujos productos ganharam definitivamente os mercados, pela superior qualidade de sua fabricação." ${ }^{26}$

Em meados da década de 1910 a fábrica de Marzagão foi adquirida pelo Sr. Manoel Tomás Carvalho de Brito. Nascido em Antônio Dias, local posteriormente incorporado ao Município de Itabira do Mato Dentro, no dia 17 de janeiro de 1872, era filho do fazendeiro e tenente-coronel da Guarda Nacional Fabriciano Felisberto de Brito e de Ana Angélica de Carvalho de Brito.

A trajetória do Sr. Carvalho de Brito é narrada em vários dicionários biográficos devido ao seu envolvimento com diversos cargos públicos. Formado em Direito pela Faculdade de São Paulo em 1894, retornou a Minas Gerais, onde exerceu o cargo de promotor da comarca de Santa Bárbara até 1897. O tipo de investidor e o perfil de empresário envolvido no decorrer do curso histórico da fábrica de Marzagão, reforça a idéia de que estes atores sociais tinham um envolvimento direito ou indireto com cargos públicos e burocráticos do poder político mineiro.

Em 1903 Carvalho de Brito foi eleito deputado federal pelo Partido Republicano Mineiro (PRM). Em 1906 assume o cargo de secretário do Interior de Minas, durante a presidência estadual de João Pinheiro da Silva. Neste momento efetua uma reforma do ensino primário estadual, sendo homenageado em uma conferência publicada em 13 de maio de 1908, pelo então diretor do Arquivo Público Mineiro e ex-presidente de Minas Gerais, Antônio Augusto de Lima.

Além de exercer suas funções associadas ao quadro burocrático mineiro do início do século XX, o Sr. Carvalho de Brito exerceu funções de banqueiro e empresário. Foi diretor do Banco do Brasil e visitou estabelecimentos industriais da Escócia e da Inglaterra a convite da

\footnotetext{
${ }^{26}$ SILVEIRA, Victor. Minas Gerais em 1925. Belo Horizonte: Imprensa Oficial, 1926. p. 1357.
} 
Federation of British Industries. Esses eventos podem ter influenciado diretamente na concepção estrutural adotada no complexo arquitetônico implantado em Marzagão. Durante o período de 1913 a 1918 foi Diretor-Presidente da Companhia de Eletricidade e Viação urbana de Belo Horizonte. Neste momento, iniciou os investimentos na fábrica de tecidos e na ampliação do conjunto arquitetônico que contava com uma usina hidrelétrica para geração de energia própria. Os investimentos na indústria em Marzagão estiveram durante muitos anos associados a atividades agrícolas, dentro da propriedade do Sr. Carvalho de Brito.

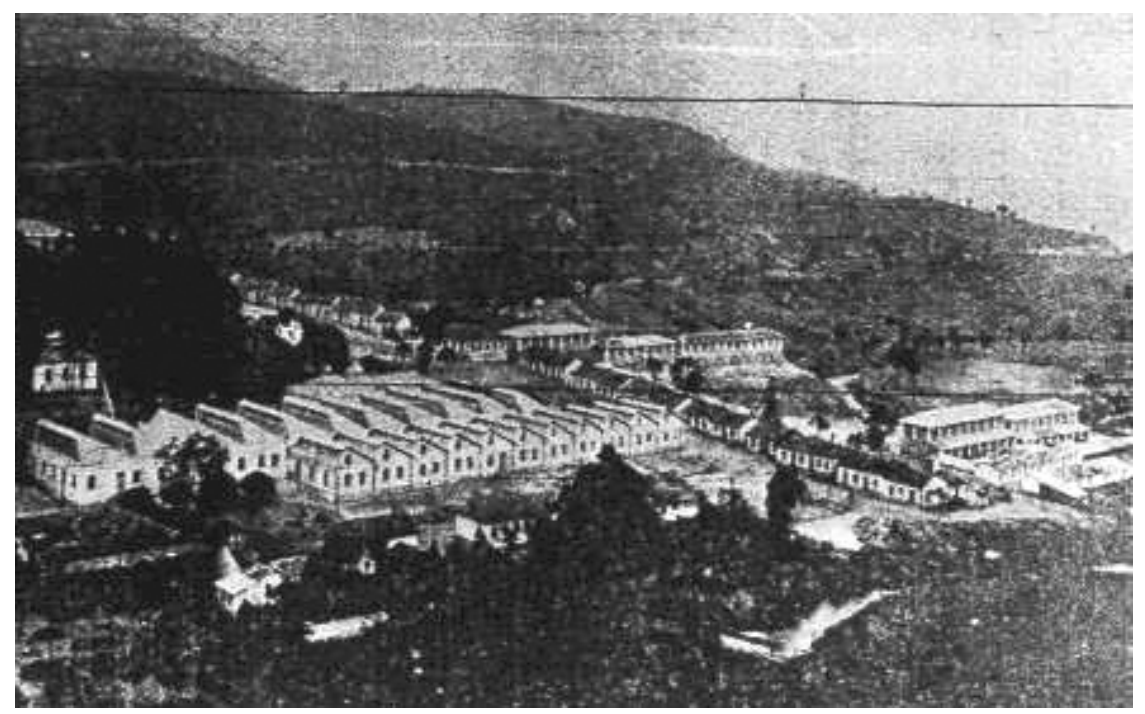

Imagem 3 - Vista parcial da fábrica e da vila operária em 1925. Fonte: Arquivo do Centro de Memória do Sistema FIEMG.

O Sr. Carvalho de Brito, representante da elite industrial mineira que mantinha estreitos vínculos políticos com o presidente Washington Luis, ao decidir apoiar a candidatura à presidência de Júlio Prestes criou sérias divergências políticas com os vitoriosos da Aliança Liberal de 1930, o que o levou a ser exilado. Retornando ao Brasil, continuou seus empreendimentos industriais e comerciais, dentre os quais destacam-se a Companhia de Fiação e Tecidos de Minas Gerais em Marzagão e a Fábrica de artefatos de borracha Pneus Brasil. Após a morte de Manoel Tomás Carvalho de Brito, em 1952, a fábrica foi administrada por seus filhos, dentre os quais se destaca Raul de Brito e seu genro, o Sr. Luís Gonzaga Nascimento e Silva, que foi casado com Vilma de Carvalho Brito do Nascimento e Silva.

O perfil dos dirigentes e empresários envolvidos com a fábrica de tecidos de Marzagão permite pensarmos na possibilidade de haver uma similaridade com outros 
empresários mineiros da mesma época. Sérgio Birchal compara as origens sociais e a origem do capital de alguns empresários brasileiros de diferentes regiões. Ao comparar mineiros com paulistas e cariocas afirma que existem características e especificidades entre estes empresários que não necessariamente podem ser aplicadas como um perfil de empresários do país no século XIX. Embora algumas fontes de capital sejam comumente convergentes para a formação de uma elite com raízes agrárias, a natureza das atividades e a origem dos empresários são variadas. O autor afirma que "a análise do empresário mineiro revela que em contraste com seus pares em São Paulo e no Rio de Janeiro, os empresários mineiros emergiram principalmente da elite local constituída basicamente de brasileiros."27

Os procedimentos de administração adotados pela família Carvalho de Brito na fábrica de Marzagão estruturaram-se em consonância com padrões de dominação que se estendiam às práticas do trabalho na fábrica de tecidos. O cotidiano do local era divulgado em matérias de periódicos da capital que enfatizavam os aspectos positivos deste empreendimento, destacando-se o conforto e a tranqüilidade que os proprietários proporcionavam aos seus operários mediante um tácito acordo de disciplina e ordenamento no trabalho.

A revista "Bello Horizonte", que era publicada na capital mineira, apresenta uma matéria descrevendo a estrutura da vila operária de Marzagão e o cotidiano dos trabalhadores neste local em 1933:

Marzagão é um pequeno arraial encostado à linha tronco da Central, no caminho para o norte, a meia hora de Belo Horizonte. A sua população é de perto de duas mil almas. É composto por gente simples, ordeira e trabalhadora. Marzagão, à tarde possue a vida corriqueira das villas do interior. Espia os trens do subúrbio, vae à reza, às vezes a um cinema mudo, um footing... No mais Marzagão trabalha. Trabalha das cinco da manhã, quando um apito forte o acorda, até que o outro apito o manda descansar, à tarde. Trabalha em que? Na lavoura, na mineração, na siderurgia? Não, Marzagão trabalha, inteirinha, numa fabrica de tecidos $[\ldots]^{28}$

O ritmo de vida moderno e a ordem estabelecida eram expostos pelos empresários como sendo o padrão de vida e um exemplo de bem-estar social a ser conquistado pelos operários. Em outras passagens da mesma publicação, observa-se que a questão salarial

\footnotetext{
27 BIRCHAL, Sérgio de Oliveira. O empresário Brasileiro: um estudo comparativo. Belo Horizonte: Ibmec working paper, 2004, p. 1.

${ }^{28}$ REVISTA BELLO HORIZONTE. O parque industrial do Marzagão, uma grande uzina de trabalho. Belo Horizonte, ano1, no 6, 30 set. 1933, p. 10.
} 
também era colocada em evidência no discurso empresarial: "Trabalham nas diversas seções da grande fábrica cerca de 1.000 operários, todos eles com ótimo salários e gozando de todas as regalias possíveis, isto muito antes da sindicalização e da criação do protetorado ao proletário." 29

A questão da formação da mão-de-obra, do recrutamento dos operários e dos limites de autonomia na fábrica de Marzagão são pontos que merecem ser discutidos. Dona Ermelinda, ex-operária da fábrica, nascida em 1919 na região do município de Santa Bárbara e moradora da vila operária de Marzagão desde 1931, relata em depoimento oral que:

Embora eu tenha começado a trabalhar com 12 anos, a vida em Marzagão era muito boa. Nessa época ainda não existia lei trabalhista. Todo empregado trabalhava de 6 da manhã até às 9 da noite com intervalo pequeno para almoço e jantar. Mas era bom. Somente até às 9 horas podíamos ficar nas ruas. Se houvesse uma festa como casamento ou aniversário, tinha que pedir licença no escritório quando a festa era à noite. Porém, não nos faltava nada, lá tinha armazém, açougue, padaria, posto médico, cinema, escola e um campo de futebol. O que não era bom é que tudo que a gente comprava era por meio do "boró" que se retirava no escritório, mas tinha que ter ganho de produção para cobrir a quantia que era pedida. ${ }^{30}$

Em outras passagens de seu depoimento esta ex-funcionária afirma que era comum haver na fábrica mulheres na faixa etária entre dez a doze anos de idade. As funções mais insalubres e que necessitavam de maior emprego de força física eram desempenhadas por homens.

\footnotetext{
29 REVISTA BELLO HORIZONTE. O parque industrial do Marzagão, uma grande uzina de trabalho. Belo Horizonte, ano1, no 6, 30 set. 1933, p. 10.

${ }^{30}$ Sra. Ermelinda de Souza Cândido. Ex-operária da fábrica de tecidos. Depoimento oral concedido a Rodrigo Pletikoszits de Ávila em fevereiro de 2007.
} 


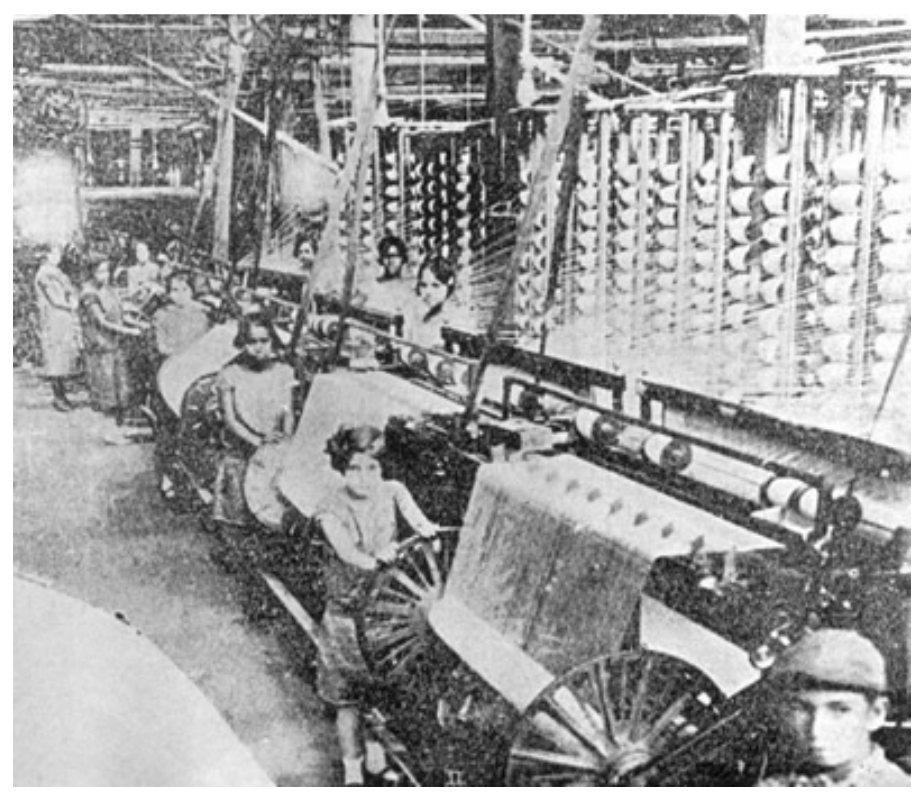

Imagem 5 - Vista do setor de teares em meados da década de 1920 Fonte: Associação dos Amigos e Moradores de Marzagão - ACAMM

O emprego de mão-de-obra infantil era comum na fábrica de Marzagão. Máquinas pesadas, como os teares mecânicos, eram operadas muitas vezes por crianças que tinham em torno de doze anos de idade. Giroletti, ao analisar o caso da fábrica do Cedro, em Curvelo, verificou que entre 1884 e 1888, 43\% do operariado eram mulheres e 33\% eram crianças.

As fábricas Companhia Industrial Sabarense e Gabiroba de Itabira também utilizaram esse tipo de mão-de-obra. Não tem referência à proporção, embora o tenham utilizado. Os alojamentos para moças no convento e para os operários solteiros são a prova de seu emprego. É provável que em proporção semelhante, para manter as condições de competitividade com as demais fábricas, a contratação maciça de mulheres (moças, senhoras e viúvas) e de meninos, além de razões expostas, se justificasse pelos baixos salários pagos e pela possibilidade de formar, entre os menores e os jovens, operários de excelente qualidade. ${ }^{31}$

O sistema de oferta de um futuro promissor e de uma vida de qualidade contrabalançava com a inexistência de direitos trabalhistas, a rigorosa disciplina e as pesadas jornadas de trabalho às quais os operários eram submetidos. A estrutura da vila operária de Marzagão antes da criação das leis trabalhistas pelo governo Vargas, na década de 1930, fornecia o acesso a bens e serviços não como um direito adquirido, mas como uma concessão e resultado do bom relacionamento entre o operariado e o patronato. Tem-se

\footnotetext{
${ }^{31}$ GIROLETTI, Domingos. Fábrica: convento e disciplina. Brasília: Editora UNB, 2002, p. 121
} 
aqui uma configuração de direitos e deveres baseados na relação inter-pessoal entre operários e patrões. O empresário criava não apenas um código de conduta para o trabalho dentro da fábrica, mas policiava, fiscalizava e até legislava, para toda a vila de maneira autônoma. Ou seja, o empresário exercia funções típicas do Estado.

Neste caso, a provisão dos direitos era uma atribuição dos detentores do capital e estabelecia-se no âmbito privado, sem a interferência estatal. Esping-Anderson, ao discutir a conceituação do Welfare state, ${ }^{32}$ expõe que:

Quando os direitos sociais adquirem o status legal e prático de direitos de propriedade, quando são invioláveis, e quando são assegurados com base na cidadania em vez de terem base no desempenho, implicam uma "desmercadorização" do status dos indivíduos vis-avis o mercado. Mas o conceito de cidadania social também envolve estratificação social: o status de cidadão vai competir com a posição de classe das pessoas, e pode mesmo substituí-lo.

$\mathrm{O}$ welfare state não pode ser compreendido em termos de direitos e garantias. Também precisamos considerar de que forma as atividades estatais se entrelaçam com o papel do mercado e da família em termos de provisão social. ${ }^{33}$

O controle e fiscalização das atividades de trabalho foram exercidas na vila de Marzagão durante o período de 1915 a 1952, pelo empresário Manoel Carvalho de Brito. Constituiu-se neste local um modelo vila/fábrica onde se estabelecia uma forma de dominação direta do operariado, com a intervenção dos empresários na vida de seus subordinados. O único armazém da região era propriedade da fábrica. A diversão era determinada em horários fixos e com atividades programadas pelos proprietários da empresa. Em matéria publicada na revista "Bello Horizonte" em 1933, assim era descrita a estrutura da fábrica:

Trabalhavam nas diversas seções da grande fábrica cerca de 1.000 operários, todos eles com ótimos salários e gozando de todas as regalias, isto muito antes da sindicalização e da criação do protetorado ao proletário. Anexa à fábrica existe uma escola de tecelagem onde trabalham atualmente cerca de 50 aprendizes. O Sr. Carvalho de Brito mandou construir para as famílias que trabalham na fábrica e que são cerca de 150, casas confortáveis e espaçosas. Para as moças solteiras existe uma pensão dirigida por senhora respeitável, onde as operárias moram e fazem as refeições. A Cia. Fiação e

\footnotetext{
${ }^{32}$ Embora o conceito de Welfare State seja muito mais robusto e merecedor de uma análise pormenorizada, associa-se aqui o termo aos tipos de relações sociais existentes em Marzagão apenas para ilustrar alguns pontos de convergência entre a idéia de cidadania e a relação de poder dos empresários com a ausência estatal em alguns setores políticos durante as primeiras décadas do século XX.

${ }^{33}$ ESPING-Anderson. As três economias do welfare state. Revista Lua Nova, no 27. CEDEC. Set. 1991, p. 101.
} 
Tecidos Minas Gerais mantém em Marzagão uma escola para os filhos dos operários, escola esta sob a direção de competente educadora. ${ }^{34}$

Além das edificações e instalações citadas acima, incluíam-se nas dependências da propriedade da fábrica um posto médico, açougue, torrefação de café, estábulo, padaria, oficinas mecânicas, carpintaria, um cartório, um posto dos correios, oficina de fundição, serraria, olaria, sede social, igreja, campo de esportes, cinema e piscina.

A seguir tem-se um croqui de algumas das edificações que existiram em Marzagão elaborado com base na observação de referências fotográficas de outras épocas e nas condições atuais de algumas edificações. Toma-se também como orientação o desenho elaborado pela equipe do Instituto do Patrimônio Histórico e Artístico de Minas Gerais, por meio do que pode ser observado em 1984, dos indícios, fundações e espaços vazios deixados pelos prédios e de algumas construções que se arruinaram ou que foram demolidas.

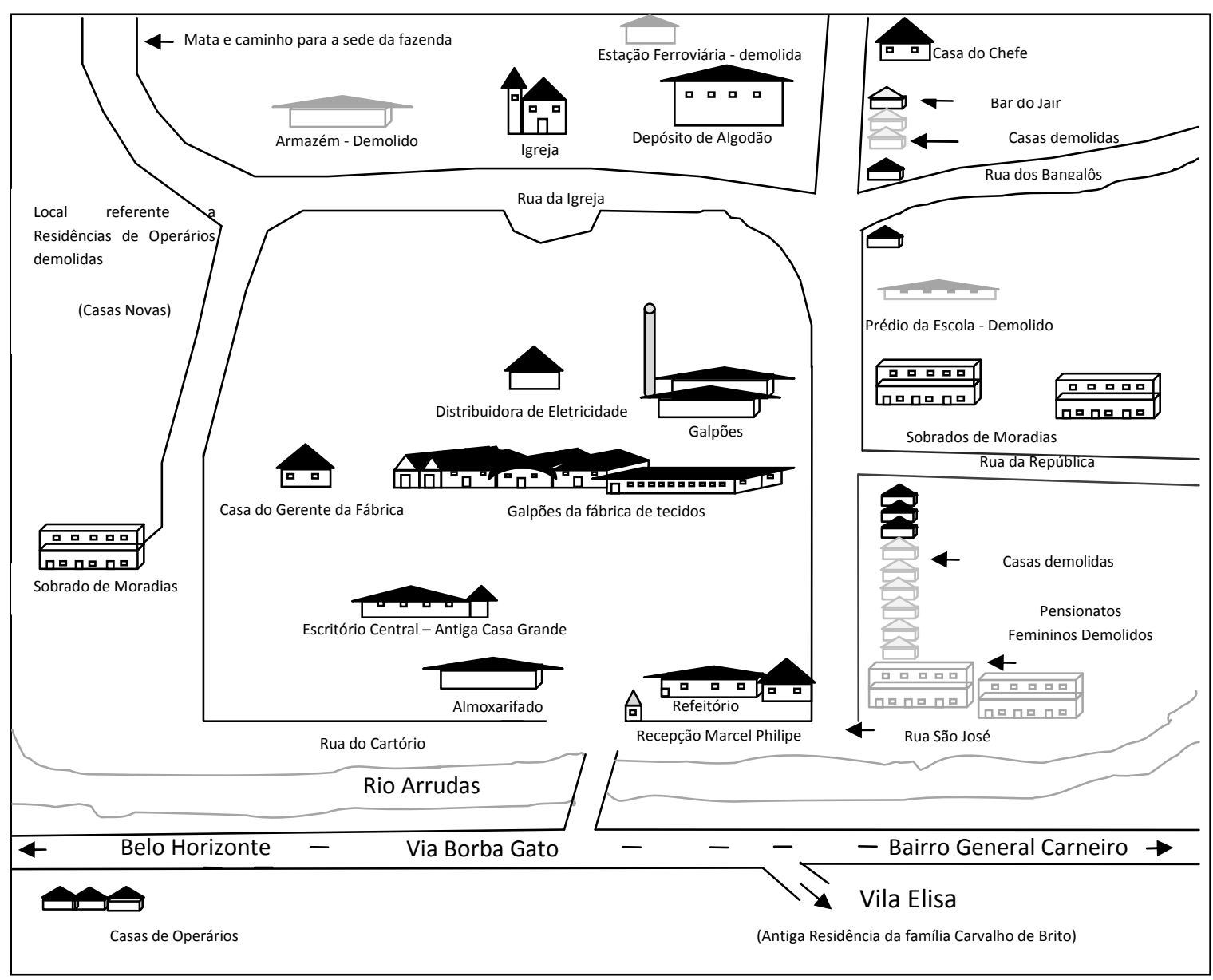

Imagem 6 - Croqui elaborado pelo autor representando parte das edificações existentes e demolidas do conjunto arquitetônico de Marzagão.

34 REVISTA BELLO HORIZONTE. O parque industrial do Marzagão, uma grande uzina de trabalho. Belo Horizonte, ano1, no 6, 30 set. 1933 
Segundo a análise arquitetônica do local, constante no parecer técnico do IEPHA-

MG:

O conjunto foi implantado em patamares, distribuindo-se a malha viária principal em duas vias transversais paralelas ao rio e duas longitudinais perpendiculares à encosta, uma delas em posição central conduzindo diretamente ao coração do núcleo representado pela rua da fábrica, e outra lateral que se subdivide na região intermediária, dando acesso às áreas residenciais à esquerda, à estação ao alto, e à rua da Igreja à direita. Uma via secundária parte da rua da fábrica levando às unidades residenciais localizadas à direita (sobrado velho e casa do encarregado), enquanto o prolongamento da rua da Igreja conduz à quadra de casas novas, hoje inexistentes, e à Fazenda Carvalho de Brito. ${ }^{35}$

Através da análise da implantação e das tipologias utilizadas, pode-se dizer que algumas características estilísticas apresentam traços e empregos formais de diferentes concepções arquitetônicas. Neste contexto, mesclam-se edifícios com traços de uma arquitetura industrial com referenciais coloniais. Tais concepções apresentam características tanto de racionalização e modernização nas técnicas construtivas quanto de uma preocupação com o conforto e a conservação de um ambiente tipicamente agrícola. Segundo a análise arquitetônica constante no dossiê de tombamento do IEPHA-MG:

Se nas casas de operários optou-se pelo emprego de esquemas formais e construtivos referenciados na arquitetura colonial, a modernidade da arquitetura eclética difundida nas últimas décadas do século XIX e início do século XX foi adotada nos edifícios industriais, nas casas do encarregado e do agente da estação, e na casa que abrigava o cartório, da qual restaram apenas ruínas de paredes. Essa convivência de repertórios arquitetônicos possivelmente corresponde ao caráter de transição da economia agrícola para a industrial típico de muitos dos conjuntos têxteis pioneiros. Entretanto, talvez estejamos diante, não da permanência daquelas soluções tradicionais, mas de uma opção por sua retomada, como se pode observar no caso da proposta de Lúcio Costa, datada da década de 1930, para a construção de vila operária em Monlevade/MG. ${ }^{36}$

Grande parte das modificações estéticas nas edificações industriais estiveram subordinadas a questões técnicas e funcionais. Neste contexto, em resposta às demandas criadas pela industrialização, começam a ser construídas edificações com características

\footnotetext{
35 INSTITUTO DO PATRIMÔNIO HISTÓRICO E ARTÍ́STICO DE MINAS GERAIS. Processo de tombamento do conjunto arquitetônico e paisagístico da fábrica de tecidos e vilaoperária de Marzagão. Belo Horizonte: IEPHA/MG, 2002.

36 Ibidem.
} 
específicas, pensadas de acordo com o programa fabril. Os edifícios e a organização espacial passam a ser elementos condicionantes de um esquema produtivo e passam a expressar uma determinada lógica de trabalho e de produção.

A distribuição e a utilização do espaço em núcleos fabris passaram a priorizar e interferir não apenas no funcionamento das máquinas, mas também ajudaram a moldar estruturas de moradias e outras composições arquitetônicas que deram origem às vilas operárias. A construção de moradias simples e funcionais, associadas a toda uma infraestrutura necessária para a manutenção da vida, sintonizavam na mesma freqüência o comportamento do indivíduo e o ritmo de funcionamento da fábrica.

A concepção de espaço de produção, que até então priorizava o funcionamento das máquinas, foi paulatinamente substituída por soluções que associavam funções inéditas às áreas típicas de produção. É o caso do agenciamento das fábricas a conjuntos habitacionais, escolas, serviços médicos, assistenciais, recreativos e religiosos. Embora esta solução, a primeira vista, significasse um benefício para os trabalhadores, em outras instâncias significava o controle quase total sobre o trabalho e a vida do operariado

Em estudo realizado sobre a vila operária de Marzagão, Lucília de Almeida Neves Delgado e Michel Marie Le Ven descrevem que:

O costume de abastecer-se no armazém da vila contribuía para aumentar ainda mais a dependência do trabalhador na empresa. Quase obrigado a fazer compras dentro da própria Marzagânia, pagando muitas vezes mais que em outros estabelecimentos, o operário sempre tinha dívidas com relação à fábrica. Havia inclusive meses em que não era pago salário porque os gastos com alimentação, água energia e moradia eram todos descontados em sua folha de pagamento. ${ }^{37}$

Esta análise nos remete a uma extensão da disciplina do interior da fábrica para a vida privada. Tal controle inibidor se pautava principalmente na propriedade, uma vez que as terras pertenciam à fábrica, e no monopólio dos bens e serviços fornecidos; e é claro, na figura de chefes disciplinadores e severos nomeados para essa função.

Em outra passagem do mesmo artigo, verifica-se que a questão da dependência e a submissão do proletariado às regras iam muito além das relações de trabalho desenvolvidas dentro da fábrica. Ao ouvir depoimentos orais de trabalhadores da fábrica, verificou-se que:

\footnotetext{
37 DELGADO, Lucília de Almeida Neves. LE VEN. Michel Marie. Marzagânia: fábrica operária e movimento sindical. Revista Brasileira de Estudos Políticos. Belo Horizonte: UFMG, № 73, 1991, p. 162.
} 
Outro mecanismo utilizado, em grande escala para reproduzir a dependência e a submissão era o sistema de distribuição de empregos. A fábrica buscava manter-se como controladora de toda a vida da comunidade construída ao seu redor. Era comum a alusão ao termo "família" com referência a comunidade de Marzagânia. Participar desta família era pressuposto de garantia de trabalho desde que fossem respeitadas as regras institucionais. $^{38}$

Exemplos deste tipo demonstram alguns dos mecanismos de controle da vida social e das atividades de trabalho aos quais eram submetidos os trabalhadores do empreendimento fabril em Marzagão. A temática do trabalho se expressa em seus desdobramentos para além das condições salariais ou técnicas de execução. $O$ trabalho pode ser um articulador entre as relações sociais e mesmo formador de um caráter identitário de grupos sociais.

Robert Castel, ao analisar as metamorfoses da questão social no caso francês, demonstra que a categoria trabalho deve ser entendida para além das relações técnicas de produção. Neste caso, a inserção ou não inserção no mercado de trabalho pode influenciar as relações sociais, culturais e identitárias de indivíduos e grupos coletivos. Castel busca no pensamento de Émile Durkheim o conceito de solidariedade como elemento fundamental para a compreensão do seu trabalho:

Émile Durkheim e os republicanos do fim do século XIX chamaram de solidariedade esse vínculo problemático que assegura a complementaridade dos componentes de uma sociedade a despeito da complexidade dos componentes de uma organização. É o fundamento do pacto social. Durkheim reformulava-o nesses termos no momento em que o desenvolvimento da industrialização ameaçava solidariedades mais antigas que ainda deviam muito à reprodução de uma ordem baseada na tradição e no costume. ${ }^{39}$

Considerações como estas nos remetem a pensarmos nos vínculos associativos e nas relações de dependência e solidariedade desenvolvidas em sociedade. Durkheim, na obra "A Divisão do Trabalho Social" afirma que nas sociedades primitivas o indivíduo está submetido à coletividade, pouco se diferenciando dos demais, sendo literalmente uma "coisa de que a sociedade dispõe". A personalidade individual é absorvida pela personalidade coletiva. Chamará este tipo de relação de "solidariedade mecânica":

\footnotetext{
38 DELGADO, Lucília de Almeida Neves. LE VEN. Michel Marie. Marzagânia: Fábrica operária e movimento sindical. Revista Brasileira de Estudos Políticos. Belo Horizonte: UFMG, № 73, 1991, p. 162.

${ }^{39}$ CASTEL, Robert. As Metamorfoses da Questão Social - Uma crônica do salário. tradução: Iraci D. Poleti 2 a ed. Petrópolis: Editora Vozes, 1999, p. 35.
} 
Essa palavra não significa que ela seja produzida por meios mecânicos e de modo artificial. Só a denominamos assim por analogia com a coesão que une entre si os elementos dos corpos vivos. O que acaba de justificar essa denominação é que o vínculo que une assim o indivíduo à sociedade é de todo análogo ao que liga a coisa à pessoa. $\mathrm{A}$ consciência individual, considerada sob esse aspecto, é uma simples dependência do tipo coletivo e segue todos os seus movimentos, como o objeto possuído segue aqueles que seu proprietário lhe imprime. ${ }^{40}$

A divisão social do trabalho, fato característico da revolução industrial, para Durkheim, rompe com essa subordinação do indivíduo ao coletivo. Ela vai ser responsável pelo processo de individualização. O indivíduo vai começar a se identificar com o seu trabalho e construir uma esfera de ação própria, por conseguinte, uma personalidade. Esta individualização vai determinar uma dependência dos indivíduos, uns em relação aos outros, promovendo uma nova espécie de solidariedade, e quanto maior é o espaço gerado pela especialização do trabalho, maior é a coesão social que resulta deste tipo de solidariedade:

Aqui, pois, a individualidade do todo aumenta ao mesmo tempo que a das partes; a sociedade torna-se mais capaz de se mover em conjunto, ao mesmo tempo em que cada um de seus elementos tem mais movimentos próprios. Essa solidariedade se assemelha à que observamos entre os animais superiores. De fato, cada órgão aí tem sua fisionomia especial, sua anatomia, e contudo a unidade do organismo é tanto maior quanto mais acentuada essa individuação das partes. Devido a essa analogia, propomos chamar de orgânica a solidariedade devida à divisão do trabalho. ${ }^{41}$

Diferentes níveis de liberdade e autonomia individual contrapondo-se com a necessidade de cooperação para o exercício da vida coletiva são alguns dos fatores que podem ser analisados em uma configuração social como a vila operária de Marzagão.

No sistema de máquinas, tem a indústria moderna o organismo de produção inteiramente objetivo que o trabalhador encontra pronto e acabado como condição material da produção. Na cooperação simples e mesmo na cooperação fundada na divisão do trabalho, a supressão do trabalhador individualizado pelo trabalhador coletivizado parece ainda ser algo mais ou menos contingente. A maquinaria, com exceções a mencionar mais tarde, só funciona por meio de trabalho diretamente coletivizado ou comum. $O$ caráter cooperativo do processo de trabalho torna-se uma necessidade técnica imposta pela natureza do próprio instrumento de trabalho. ${ }^{42}$

\footnotetext{
40 DURKHEIM, Émile. Da Divisão do Trabalho Social. São Paulo: Editora Martins Fontes, 1995, Tradução: Eduardo Brandão, p. 107.

41 Ibidem, p.109

42 Marx apud GIROLETTI, Domingos. Fábrica: convento e disciplina. Brasília: Editora UNB, 2002, p.58.
} 
O trabalho, enquanto elemento central da análise das relações sociais existentes em Marzagão, demonstra ser um campo amplo e passível de interpretações e leituras que ultrapassam as barreiras das questões trabalhistas. Os tipos de organização social e as estruturas de dependência entre os indivíduos podem resultar em relações sociais com níveis de interação diferenciados. No caso específico de Marzagão, os operários tinham diversos setores da vida cotidiana vinculados a instituições que também eram controladas pelos proprietários do local. Margareth Rago, ao analisar as vilas operárias da cidade de São Paulo, argumenta que:

(...) Na verdade, todos os movimentos do operário, sua postura, seus atos, seu ritmo de trabalho, sua própria história pessoal e profissional são objeto de um controle disciplinar à imagem de um acampamento militar, objetivando-se extrair o máximo rendimento e anestesiar a explosão da revolta latente. ${ }^{43}$

José Ricardo Ramalho, ao analisar as transformações do modelo de produção baseado na relação direta entre capital e trabalho, faz um estudo de caso da Fábrica de Motores Nacional, FNM, que foi implantada no Estado do Rio de Janeiro na década de 1940. Embora se trate de ramo de atividade distinta, alguns aspectos são análogos ao caso da vila operária de Marzagão. Ramalho destaca a disciplina como sendo um dos fatores primordiais na formação do operariado da referida fábrica, que neste caso sofreu influências militares, pois a mesma estava sob a direção de um militar, o Brigadeiro Guedes Muniz.

A presença física do "Brigadeiro" em momentos importantes para a vida dos trabalhadores na fábrica e a relação face a face que mantinha serviam não só para consolidar este estilo de "dominação" como para transformar estes momentos em encenações, onde o poder do patrão se concretizava de forma exemplar. ${ }^{44}$

Relações patronais nas quais a autoridade e o controle da mão-de-obra foram construídos com bases paternalistas também eram recorrentes durante o período de implantação de indústrias em Minas Gerais. Neste caso, o controle das atividades era fiscalizado diretamente pelo patrão que criava formas bastante pessoais de exercício do poder. Domingos Giroletti, ao pesquisar a formação das indústrias têxteis mineiras, destaca

\footnotetext{
43 RAGO, Margareth. Do Cabaré ao Lar: a utopia da cidade disciplinar: 1890-1930. 3 ed. Rio de Janeiro: Paz e Terra, 1997, p. 23-24.

44 RAMALHO, José Ricardo. Estado-Patrão e luta operária: o caso FNM. Rio de Janeiro: Paz e Terra, 1989, p.78.
} 
o elemento disciplinar existente na Cedro Cachoeira, São Vicente, São Sebastião, entre outras. Segundo Giroletti:

A disciplina foi produzida pela ação direta dos empresários, manipulando recursos de ordem econômica e política de que dispunham, ou pela ação indireta de agentes por ele contratados, ou pelos mesmos introduzidas (Igreja, Escola) ou especialmente criadas, como o Convento. Da ação orquestrada destas várias agências resultou a produção do operário disciplinado, sujeito à vontade dos empresários. ${ }^{45}$

Quando um grupo social se confunde com uma determinada extensão territorial e se faz integrado a ela, adquire um caráter peculiar. Como exemplo pode-se citar a reunião de pessoas formando um estado ou uma cidade, onde grupos de indivíduos encontram-se ligados pelo território. A influência do espaço sobre as relações sociais ultrapassa os limites do território físico e mensurável. Para Simmel, “(...) o espaço não é mais que uma atividade da alma, a maneira que têm os homens de reunir, em instituições unitárias, os efeitos sensoriais que em si não possuem laço algum." ${ }^{46}$

O ritmo de vida, na Vila Marzagão era influenciado pela disposição arquitetônica e pelos limites da própria vila onde se tinha bem delimitado o espaço utilizado pelo patrão e as residências dos operários. As atividades dos moradores sofriam influências diretas da marcação de tempo e ritmo imposto pelo trabalho na fábrica.

\section{O DECLÍNIO DA ATIVIDADE FABRIL E A DESESTRUTURAÇÃO DA VILA OPERÁRIA}

A falta de investimentos e aquisição de novas máquinas durante a década de 1950, associada a morte do presidente da indústria, o sr. Manoel Thomás Carvalho de Brito, fizeram com que a lucratividade da fábrica começasse a decair. A administração da fábrica passou a ser exercida pelos descendentes da família Carvalho de Brito, dentre os quais já foram citados o seu filho, Raul de Brito e seu genro Luís Gonzaga Nascimento e Silva. A solução encontrada pelos empresários para recuperar a lucratividade sem investir na aquisição de novas máquinas foi diversificar a produção. Sendo assim, a produção de tecidos

\footnotetext{
${ }^{45}$ GIROLETTI. Domingos. Fábrica: Convento e Disciplina. Brasília: Editora UNB, 2002. P.18.

46 SIMMEL, Georg. "El Espacio y la sociedad" In: Idem. Sociologia: estudios sobre las formas de socialización. Buenos Aires: Espaça-Calpe, 1939, p. 208.
} 
passou a ser crescentemente substituída pela produção de lonas e cordonéis para abastecer a indústria pneumática Pneus Brasil de propriedade da família, com sede no Rio de Janeiro. Essa indústria era beneficiada por incentivos fiscais federais e detinha grande parte da produção deste setor no país.

Com a vitória de Juscelino Kubstichek à presidência da República, em 1955, e a implantação de seu plano desenvolvimentista, o grupo empresarial de Marzagão perdeu o subsídio estatal. Além disso, teve de enfrentar a concorrência de indústrias estrangeiras. "Pressionada pelas circunstâncias o grupo se viu compelido a diversificar novamente sua produção. Então adquiriu máquinas novas." 47 Neste período as condições de trabalho tornavam-se cada vez mais precárias. Segundo Delgado e Le Ven, "A manipulação de um maquinário pesado produzia graves problemas de saúde nos operários." 48 Diante dessas condições, as comissões de fábrica criadas pelos funcionários passaram a organizar greves para reivindicar os pagamentos que começavam a atrasar.

O modelo paternalista começou a apresentar falhas e os movimentos reivindicatórios tornaram-se crescentes. O movimento operário desenvolvido no interior da vila operária de Marzagão teve algumas particularidades, pois além de atuar de maneira autônoma em relação ao sindicato oficial, as comissões de fábrica tiveram um importante auxílio de representantes da Igreja Católica.

\begin{abstract}
A prática mais comum do sindicalismo no período populista estava vinculada aos partidos PCB, PTB e ao Estado. Com o Estado o movimento sindical desenvolvia uma relação que se processava através de um duplo caminho: $O$ principal interlocutor para negociações de salários ou de outra natureza era o Estado e não as empresas em particular. Nesse procedimento a justiça do trabalho exercia importante função. Em Marzagânia, entretanto, a dinâmica das lutas sindicais ocorreu seguindo outra lógica, e a organização interna dos trabalhadores, apesar do paternalismo e do rígido controle da empresa, se desenvolveu, pelo menos a princípio, configurada por uma grande independência com relação aos partidos e ao sindicato oficial, e em conseqüência dessa última condição também ao Estado. ${ }^{49}$
\end{abstract}

No fim do ano de 1960, após seis meses de salários atrasados, os líderes sindicais aproximaram-se da comissão de fábrica que organizou uma manifestação de grande repercussão. Percebe-se que o isolamento, não só político, mas também geográfico, da vila

\footnotetext{
47 DELGADO, Lucília de Almeida Neves. LE VEM, Michel Marie. Marzagânia: fábrica operária e movimento sindical. Revista Brasileira de Estudos Políticos. Belo Horizonte: UFMG, № 73, 1991, p. 160.

48 Ibidem, ibidem.

49 Ibidem, p. 167.
} 
não impedia a ação ordenada da classe operária, mesmo sem vínculos estreitos com os grupos sindicais.

Em matéria publicada no jornal do município de Sabará, são descritos os motivos e as condições em que supostamente teriam ocorrido o movimento grevista e a mobilização desta população até então disciplinada e controlada pelos laços paternalistas da vila operária. Tem-se no título da matéria o seguinte: "Seis meses de atrasados levam à greve por mais de 30 dias, os têxteis de Marzagânia - Nascido em berço de ouro, Raul de Brito não

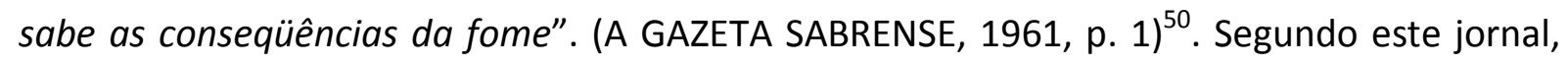
em um primeiro momento, o movimento grevista teve apoio e amparo de membros da igreja católica e de outros empresários, como podemos observar na seguinte passagem da matéria:

A destacada atuação de Sua Excelência o Exmo. Senhor Arcebispo Coadjutor, D. João Rezende Costa, que esteve em Marzagânia e tomou conhecimento da onda de sofrimento existente, prometeu empreender todos os esforços em favor dos grevistas. Sua primeira providência foi solicitar do Sr. Oswaldo Melo, proprietário da empresa "Asa Branca" um caminhão lotado de mantimento para distribuição ao povo. ${ }^{51}$

O movimento grevista, que contou com o apoio do então presidente da Federação dos trabalhadores Têxteis, Sr. Sinval Bambirra, realizou uma grande passeata que foi noticiada em diversos jornais mineiros e de outras localidades do país. O jornal "Última Hora", do Rio de Janeiro, assim descreveu o movimento:

\begin{abstract}
Mais de dois mil trabalhadores acompanharam ontem os grevistas da Companhia de Fiação de Tecelagem de Marzagânia em sua "passeata da fome" pelas ruas da cidade, que teve seu final no Palácio da Liberdade, onde os dirigentes sindicais foram recebidos pelo chefe de gabinete do governador. Durante todo o percurso da passeata, populares aplaudiam os trabalhadores, que portavam faixas onde se lia "pagamento ou morte" e os operários não podem pagar pelos erros dos patrões. O movimento se dissolveu, posteriormente, sem perturbação da ordem. ${ }^{52}$
\end{abstract}

Sinval Bambirra, que coordenador das negociações e do movimento grevista de Marzagânia neste período, em depoimento oral concedido à Lucília Neves, afirmou que a fábrica, além de estar entre uma das que tinham os equipamentos mais antigos e pesados,

\footnotetext{
50 A GAZETA SABARENSE. Sabará, 2a quinzena de janeiro de 1961, no 9. p. 1.

51 A GAZETA SABARENSE. Sabará, 2a quinzena de janeiro de 1961, no 9, p. 1.

52 ÚlTIMA HORA. Rio de janeiro, 20 de Janeiro de 1661, ano X, p. 1.
} 
explorava a mão-de-obra dos funcionários através de uma prática de precarização do trabalho conhecida como ziguezague. Segundo este: "Zigue-zague é uma barbaridade, é, o trabalhador fica a disposição da empresa, doze horas, mas só recebe oito. Porque ele trabalha quatro horas, sai da empresa, fica em casa quatro horas, e volta pra trabalhar mais quatro." 53

As alterações na lógica do trabalho capitalista ocorreram de maneira gradativa no território da fábrica de Marzagão. A incorporação das transformações de mercado, associada a um contexto político e macroeconômico específico, produziu efeitos que refletem uma tendência mundial de crise estrutural do capital.

Em suma, o período de implantação econômica da vila operária de Marzagão é marcado por transformações estruturais do capital. No século XIX ocorre a transição de um modelo econômico baseado na mão-de-obra escrava para o trabalho assalariado, entre o moderno e o arcaico, a atividade agrícola e a atividade fabril mecanizada, a monarquia e a república. Projetos utópicos e garantia de emprego, salário e condições de vida digna foram propostas que permearam o período de apogeu da vila operária durante as primeiras décadas do século XX. Estas ofertas de melhorias das condições de vida estiveram associadas a uma relação ambivalente que transitou entre o cerceamento de liberdades individuais e a idéia de bem-estar coletivo.

As propostas de bem-estar na vila operária de Marzagão, em seu período de pujança econômica, basearam-se em relações que se manifestaram no âmbito da esfera privada, nas quais empresários exerciam atividades típicas do Estado. Criou-se nesse grupo social uma relação paternalista que controlava não somente as relações de trabalho, mas todas as esferas da vida e do cotidiano do morador da vila operária.

A crise do setor produtivo delineada em fins da década de 1950 trouxe à tona as contradições e novas perspectivas de transformações da estrutura do capital, que culminaram na decadência da atividade fabril na vila operária de Marzagão.

Após esses acontecimentos, a estrutura da fábrica foi se precarizando. A decadência econômica não pôde ser evitada, o que acarretou em conseqüentes demissões e redução das atividades industriais no complexo fabril ao longo da década de 1960. Em 1972 as

\footnotetext{
53 BAMBIRRA, Sinval. Depoimento Oral prestado a Lucília de Almeida Neves Delgado. Programa de História Oral da FAFICH-UFMG. 1990, FITA no 4.
} 
instalações da fábrica e a usina hidrelétrica foram vendidas para a Companhia de Fiação e Tecidos Cedro Cachoeira. A maior parte dos operários já havia sido demitida entre fins da década de 1960 e 1970. Vários funcionários mudaram-se da vila e adquiriram terrenos em bairros próximos que surgiram de parcelamentos da propriedade da própria família Carvalho de Brito. O complexo de Marzagão, que freqüentemente recorria às inovações tecnológicas de um maquinário geralmente importado, deparou-se neste momento com um maquinário obsoleto e sem condições fiscais favoráveis para competir com o mercado externo.

A Companhia Cedro Cachoeira, que adquiriu o complexo industrial da fábrica, retirou o maquinário e vendeu os galpões para a empresa de confecções Top (Marcel Philippe), que transferiu sua sede do bairro Santa Tereza, em Belo Horizonte, e instalou-se na região no início da década de 1980, onde utiliza os edifícios até os dias de hoje. 